\title{
Have IT improvements had positive impacts on international trade?
}

\author{
Y. Kurihara ${ }^{a}{ }^{*}$ \\ a Department of Economics, Aichi University, Nagoya, Aichi, Japan \\ *Corresponding author Ph.No : 81-52-564-6111; Email: kurihara@vega.aichi-u.ac.jp \\ DOI: https://doi.org/10.54392/ajir2141 \\ Received: 02-09-2021; Revised: 11-10-2021; Accepted: 12-10-2021 Published: 15-10-2021
}

\begin{abstract}
IT (Information Technology) was invented and penetrated into our daily lives and business world from the 1980s. It has also spread quickly in developed economies. This study examines whether such phenomenon has impacted international trade. More concretely, this study empirically examines the relationship (1) between the improvement of banking and financial services and international trade, (2) between the Internet speed and international trade, and (3) mobile subscribers and international trade. The empirical results show that GDP per capita is positively related with international trade significantly. Moreover, they show that banking and financial services can increase international trade. Also, Internet speed is significantly associated with promoting international trade. However, there is no evidence that the spreading use of mobile has caused increasing international trade. If the pros of the spreading use of mobile related IT are large, there is some room for promoting this transition. Security, reliability, and so on are key factors to promote mobile into business, including international trade.
\end{abstract}

Keywords: Banking and financial service, International trade, IT, Mobile

\section{Introduction}

The Internet has been established largely all over the world since the early 1980s. It has reduced many trade-related barriers. Also, it has reduced time and the disadvantage of location and has encouraged efficiency in many fields. It surely expands possibilities.

It cannot be denied that IT, especially the Internet, has helped to promote international trade. However, there is some possibility that the spreading usage of mobile-type IT, for example, mobile phone, has also facilitated increased international trade. There has been a lot of papers presented for the relationship between IT and international trade, however, there have been few papers to examine the association between mobile-type IT and international trade. This study's point is this. It analyzes the relationship between mobile-type IT and international trade empirically.

Many studies have shown that revolutionary improvements of IT have had a significant role in the development of international trade. However, some of the important channels through that new IT having impacts on international trade have not been fully analyzed. As (Milica, 2018) showed, it seems natural that large changes will occur in the international trading process and its structure. This paper focuses on the role of mobile-type IT on international trade.

This study is structured as follows. Section 2 reviews the existing related studies. Section 3 presents an empirical method. Following this section, empirical analyses are conducted and the results are provided. Finally, a brief summary is presented.

\section{Recent Trends and Existing Studies}

Figure 1 shows the internet users all over the world. As figure 1 shows, users have been increasing, and almost all people use it in developed economies now. 


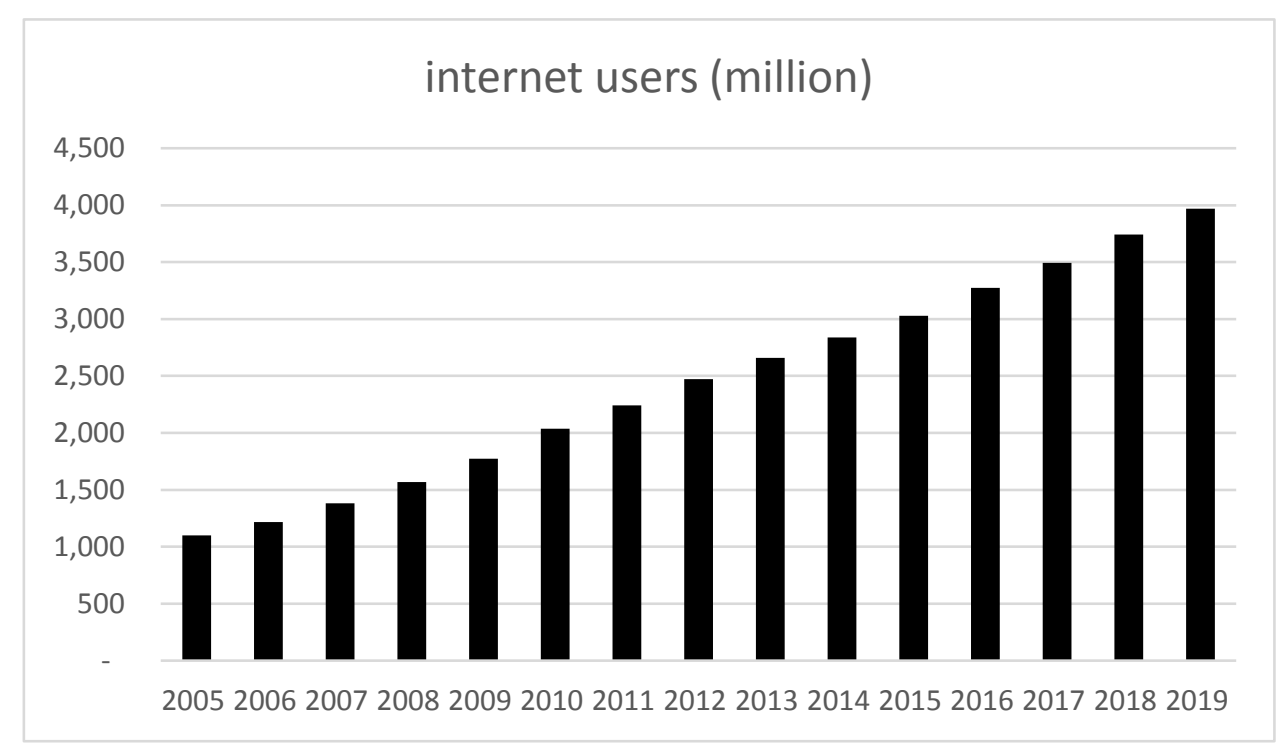

Figure 1 Internet users all over the world

Source: Key ICT indicators for developed and developing countries, the world and special regions (totals and penetration rates)

It should be noted that the number of mobile subscribers has been increasing not only in developed economies but also in developing economies. One reason is that some infrastructures can be equipped easily with low cost. Figure 2 is the number of mobile phone subscribers in six economies.

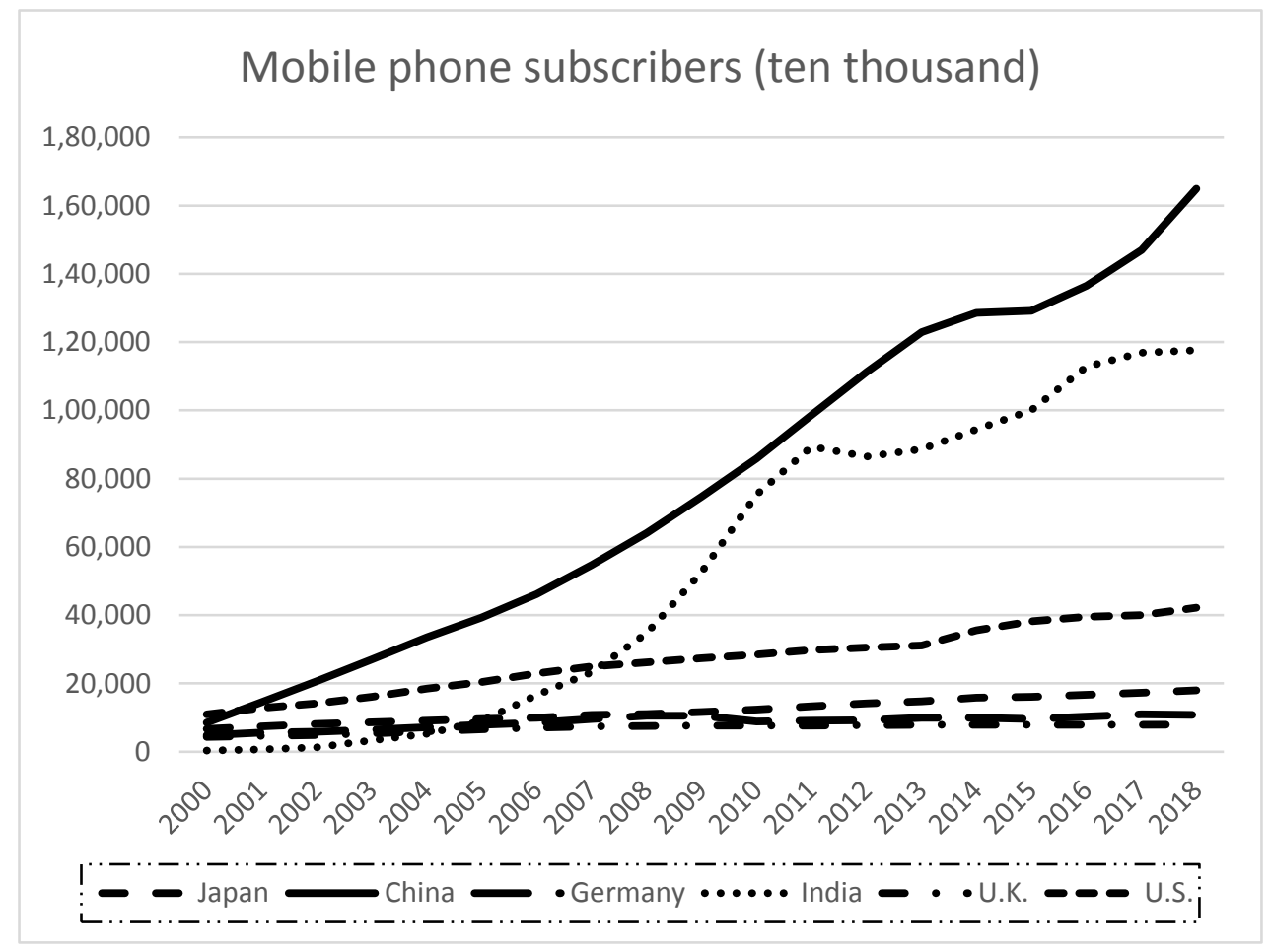

Figure 2 Mobile phone subscriber (ten thousand)

Source: ITU World Telecommunication/ICT Indicators 2020

There have been a lot of excellent studies provided for the field of IT and international trade. In general, studies presented in the 1980s and 1990s showed that the relationship between IT productivity and economic growth was not so large (Oliner and Sichel, 2000) or they were vague. On the other hand, positive relationships have also been found (Noh and Yoo, 2008; Choi and Hoon, 2009).

Many studies have shown that the Internet promotes international trade due to expanded trade opportunities (Wallstem, 2006; Clarke, 2008; Vemuri and Siddigi, 2009). Clarke and Wallsten (2006) suggested that access to the 
Internet improved export volume in developing economies, however, not in developed countries. Meijers (2014) found that the Internet's effects on international trade are greater in lower income economies than in high income economies, on the other hand, the effects of world trade on economic growth was almost the same for both incometype groups. Hjort and Poulsen (2019) found large positive effects on employment rates by introducing fast Internet systems in Africa. Hajilee and Niroomand (2019) indicated that financial market penetration of Internet had significantly changed many fields in the short-term and had at the same time impacted the openness of international trade (trade volume/GDP, for example) of emerging economies. Abeliansky, Barbero, and Rodriguez-Crespo (2021) revealed significant evidence that ICTs influenced the existence margin of international trade and the movement is bigger for developing economies from the view of quality.

Vemuri and Siddiqi (2009) found that there existed a positive impact of ICT infrastructures and the usage of the Internet for commercial transactions on the volume of international trade. Lin (2015) showed that a 10\% increase in the Internet subscribers facilitates international trade by $0.2 \%-0.4 \%$ increases. The results are not sensitive to situations such as adding time-varying economy while fixed effects into the gravity and controlling for infrastructure measures were taken into consideration in the empirical models. Gnangnon and Iyer (2018) found that the reduction of the Internet-related geographical distance would improve countries' integration in reality into the international trade in the field of commercial services markets. Gnangnon (2020) indicated that easy access to the Internet is positively related with the diversification of services' exports.

However, Hakanson and Dow (2012) suggested that the impact of distance has not decreased so largely for homogenous goods; on the other hand, for the case of differentiated goods, the distance has declined slightly. Kneller and Timmis (2016) found evidence for a caused effect from the Internet on world trade in business services, but it showed no evidence for an effect on international trade in services more generally. Visser (2019) indicated that there was a positive and significant relationship between an increase in Internet usage and not only the extensive but also intensive margins of differentiated export products. Billon and Rodriguez-Crespo (2020) showed a negative impact of trade promotion on bilateral trade and an inverse association between ICT usage and international trade promotion because of hindering the potential benefits of ICT use in intra-Sub-Saharan African trade.

This study focuses on the relationship between IT and IT-related financial services. Hur, Raji, and Riyanto (2006) showed that countries which enjoy high levels of financial development gain higher export shares and surplus in bilateral international trade balance in industries with more intangible assets. Demir and Dahi (2011) found that the results which examined by employing dynamic panel regressions methods and comprehensive sensitivity tests, financial development in the Southern countries has positive and significant impacts on the share of total and technology-and-skill-intensive manufactures exports to GDP.

The relationship between mobile-type IT and international trade is the main topic in this study. However, there is little study focusing on this topic. Donovan (2012) found that while the poor can use mobile money to facilitate their possibilities, innovative offerings require strong demand from consumers and firms, which is variable missing in many cases, and because this industry exists in the interaction of banking and telecommunications, some countries have different regulation practices. Interoperability problems, as well as clashes in culture between banks and mobile operators, challenge cross-sectoral partnerships. Asongu (2013) showed that mobile phone invasion may not be evaluated at a macroeconomic level significantly by traditionally presented financial improvements indexes. Finally, Sawadogo and Wandaogo (2021) indicated that countries that employed mobile money showed a higher products international trade share in GDP of 0.6 percent in comparison to non-subscribers.

\section{Empirical methods}

To examine the relationship between IT-related subjects and international trade, gravity model is used for estimations. The gravity model has been introduced and cited many times to examine international trade. Bilateral trade is analyzed in many cases. Not only academic fields but also real-world researchers have employed this analysis method.

Krugman (2001) theoretically stated that if trade promotes production specialization, industry-specific shocks to the economy lead to divergent business cycles and that comparative advantages do not accomplish the relationships which the theory suggest in the gravity model. Alternatively, Baldwin (2006) showed that promoting 
international trade integration may be related to national incomes. The dependent variable is bilateral trade volume (export plus import) between the bilateral countries. As these, the independent variables are GDP (per capita) and distance (usually between the capitals) are employed for empirical analyses in the gravity model.

The typical equation is as follows (1).

$$
X i j=a \frac{Y i Y j}{D i j}
$$

$X$ stands for international trade. $Y$ denotes economic size (income per capita), D denotes distance, $i, j$ denote countries, and $a$ is a constant term.

This study uses population and GDP per capita. Distance is not used for estimation because the effect of the distance on international trade has been decreasing as some studies suggested (See, Kurihara and Fukushima, 2016, for example). Moreover, Banking \& financial services, Mobile subscribers, and Internet speed are used for estimation. The equation is as follows (1).

$\log \left(\right.$ TRADE $\left._{i t}\right)=a 1+a 2 \log \left(\right.$ population $\left._{i t}\right)+a 3 \log ($ GDP per capitai $)+a 4$ Banking \& financial servicesit $+a 5$ Mobile subscribersit $+a 7$ Internet speed ${ }_{i t}+u_{i j}$

$\log \left(\right.$ EXPORT $\left._{i t}\right)=a 1+a 2 \log \left(\right.$ population $\left._{i t}\right)+a 3 \log ($ GDP per capitai $)+a 4$ Banking \& financial servicesit $+a 5$ Mobile subscribersit $+a 7$ Internet speed $d_{i t}+u_{i j}$

$\log \left(\right.$ IMPORT $\left._{\text {it }}\right)=a 1+a 2 \log \left(\right.$ population $\left._{i t}\right)+a 3 \log ($ GDP per capitai $)+a 4$ Banking \& financial servicesit $+a 5$ Mobile subscribersit $+a 7$ Internet speed $d_{i t}+u_{i j}$

where TRADEi, EXPORTi, IMPORTi are the percentage of international trade of country $i$ to GDP. i means a country. TRADE is the total volume. Population denotes the number of population in each country, and GDP per capita is GDP per capita of each country. They are from International Financial Statistics and Direction of Trade Statistics and both of them are from the IMF. Banking \& financial services, Mobile subscribers, and Internet speed are from IMD.

The IMD World Competitiveness Yearbook (WCY), first published in 1989, is a comprehensive annual report and worldwide reference point on the competitiveness of countries. It provides benchmarking and trends, as well as statistics and survey data based on extensive research. It analyzes and ranks countries according to how they manage their competencies to achieve long-term value creation (IMD; https://worldcompetitiveness.imd.org/Copyright?returnUrl=\%2Frankings\%2Fwcy).

In this book, the analysis of banking and financial services is 'banking and financial services do support business activities efficiently', mobile broadband subscribers is ' $4 \mathrm{G} \& 5 \mathrm{G}$ market, \% of mobile market' and Internet bandwidth speed is 'average speed'. The variables of ordering countries are used for export and import cases and the average data are used for the case of trade volume (export plus import).

The estimated countries are Argentina, Australia, Austria, Belgium, Brazil, Bulgaria, Canada, Chile, Columbia, China, Columbia, Croatia, Czech Republic, Denmark, Estonia, Finland, France, Germany, Greece, Hong Kong SAR, Hungary, Iceland, India, Iceland, Ireland, Israel, Italy, Japan, Jordan, Kazakhstan, Korea Rep. Latvia, Lithuania, Luxemburg, Malaysia, Mexico, Netherlands, New Zealand, Norway, Peru, Philippine, Poland, Portugal, Qatar, Rumania, Russia, Singapore, Slovak, Republic Slovenia, South Africa, Spain, Sweden, Switzerland, Taiwan China, Thailand, Turkey, UAE, Ukraine, United Kingdom, USA, and Venezuela. The sample period is from 2001 to 2020. The data was collected yearly.

Panel data is used for estimations. Along with the Least Squares, robust estimation (RS) is used for estimations. RS is unlike maximum likelihood estimation. OLS estimates for regression are usually sensitive to the variables that do not obey the pattern of the other ones. This is not a problem if the outlier is extreme from the tail of a normal distribution, however, if the outlier is from non-normal measurement error or some other violation of normal OLS estimation, it can solve the suitability of the regression.

The statistical descriptions of the three variables are in Table 1. 
Table 1 Statistical descriptions of three variables

\begin{tabular}{|l|l|l|l|}
\hline & Banking \& financial services & Mobile subscribers & Internet speed \\
\hline Mean & 6.113 & 63.072 & 41.121 \\
\hline Median & 6.378 & 67.800 & 36.759 \\
\hline Maximum & 8.215 & 100.000 & 119.118 \\
\hline Minimum & 1.755 & -1.500 & 1.998 \\
\hline Std. Dev. & 1.257 & 22.269 & 24.494 \\
\hline Skewness & -0.796 & -0.621 & 0.902 \\
\hline Kurtosis & 3.362 & 2.797 & 3.429 \\
\hline Jarque-Bera & 21.002 & 12.487 & 27.104 \\
\hline probability & 0.000 & 0.001 & 0.000 \\
\hline
\end{tabular}

\section{Empirical results}

Empirical results of the equation (2), (3), and (4) are Table 2, Table 3, and Table 4.

Table 2 International trade

\begin{tabular}{|c|c|c|c|c|}
\hline \multirow[b]{2}{*}{ C } & \multicolumn{2}{|c|}{ LS } & \multicolumn{2}{|c|}{ RS } \\
\hline & $\begin{array}{l}-14.370 * \\
(-1.722)\end{array}$ & $\begin{array}{l}10.807 \\
(0.511)\end{array}$ & $\begin{array}{l}18.766 * * * \\
(3.459)\end{array}$ & $\begin{array}{l}23.508 \\
(1.499)\end{array}$ \\
\hline Log (population) & $\begin{array}{l}-1.752 * * * \\
(--2.847)\end{array}$ & $\begin{array}{l}-4.668 * * \\
(-2.583)\end{array}$ & $\begin{array}{l}-3.288 * * * \\
(-7.632)\end{array}$ & $\begin{array}{l}-4.675 * * * \\
(-3.486)\end{array}$ \\
\hline $\begin{array}{c}\text { Log } \\
\text { (GDP/per capita) }\end{array}$ & $\begin{array}{l}2.607 * * * \\
(2.957)\end{array}$ & $\begin{array}{l}1.290 \\
(0.529)\end{array}$ & $\begin{array}{l}0.428 \\
(0.748)\end{array}$ & $\begin{array}{l}0.310 \\
(0.171)\end{array}$ \\
\hline Banking \& financial services & $\begin{array}{l}4.801 * * * \\
(7.171)\end{array}$ & & $\begin{array}{l}1.835^{* * *} \\
(4.215)\end{array}$ & \\
\hline Mobile subscribers & & $\begin{array}{l}0.111 \\
(1.080)\end{array}$ & & $\begin{array}{l}0.061 \\
(0.804)\end{array}$ \\
\hline Internet speed & & $\begin{array}{l}0.264 * * \\
(2.562)\end{array}$ & & $\begin{array}{l}0.095^{*} \\
(1.802)\end{array}$ \\
\hline Adj.R2 & 0.071 & 0.128 & & \\
\hline Adj.Rw2 & & & 0.068 & 0.138 \\
\hline $\begin{array}{c}\text { F-statistic } \\
\text { (probability) }\end{array}$ & $\begin{array}{l}27.353 \\
(0.000)\end{array}$ & $\begin{array}{l}7.794 \\
(0.000)\end{array}$ & & \\
\hline $\begin{array}{c}\text { Rn-squared statistic } \\
\text { (probability) }\end{array}$ & & & $\begin{array}{l}68.922 \\
(0.000)\end{array}$ & $\begin{array}{l}20.989 \\
(0.000)\end{array}$ \\
\hline
\end{tabular}

Note: Parentheses are t-value. $* * *, * *, *$ denotes significant at 1,5 , and $10 \%$ respectively. 
Table 3 Export

\begin{tabular}{|c|c|c|c|c|}
\hline \multirow[b]{2}{*}{ C } & \multicolumn{2}{|l|}{ LS } & \multicolumn{2}{|l|}{ RS } \\
\hline & $\begin{array}{l}-35.382 * * * \\
(-3.401)\end{array}$ & $\begin{array}{l}-40.804 \\
(-1.510)\end{array}$ & $\begin{array}{l}25.226 * * * \\
(3.648)\end{array}$ & $\begin{array}{l}19.748 \\
(0.940)\end{array}$ \\
\hline Log (population) & $\begin{array}{l}-1.436 * \\
(-1.739)\end{array}$ & $\begin{array}{l}-0.871 \\
(-0.357)\end{array}$ & $\begin{array}{l}-3.866 * * * \\
(-7.050)\end{array}$ & $\begin{array}{l}-6.949 * * * \\
(-3.681)\end{array}$ \\
\hline Log (GDP/per capita) & $\begin{array}{l}5.412 * * * \\
(4.945)\end{array}$ & $\begin{array}{l}9.480 * * * \\
(3.056)\end{array}$ & $\begin{array}{l}0.694 \\
(0.956)\end{array}$ & $\begin{array}{l}3.063 \\
(1.273)\end{array}$ \\
\hline Banking \& financial services & $\begin{array}{l}5.618^{* * *} \\
(6.748)\end{array}$ & & $\begin{array}{l}1.970 * * * \\
(3.560)\end{array}$ & \\
\hline Mobile subscribers & & $\begin{array}{l}-0.304 * * \\
(-2.345)\end{array}$ & & $\begin{array}{l}-0.051 \\
(-0.511)\end{array}$ \\
\hline Internet speed & & $\begin{array}{l}0.437 * * * \\
(3.501)\end{array}$ & & $\begin{array}{l}0.023 \\
(0.237)\end{array}$ \\
\hline Adj.R2 & 0.086 & 0.156 & & \\
\hline Adj.Rw2 & & & 0.065 & 0.113 \\
\hline $\begin{array}{c}\text { F-statistic } \\
\text { (probability) }\end{array}$ & $\begin{array}{l}33.061 \\
(0.000)\end{array}$ & $\begin{array}{l}9.690 \\
(0.000)\end{array}$ & & \\
\hline $\begin{array}{c}\text { Rn-squared statistic } \\
\text { (probability) }\end{array}$ & & & $\begin{array}{l}57.946 \\
(0.000)\end{array}$ & $\begin{array}{l}16.852 \\
(0.002)\end{array}$ \\
\hline
\end{tabular}

Note: Parentheses are t-value. $* * *, * *, *$ denotes significant at 1,5 , and $10 \%$ respectively.

Table 4 Import

\begin{tabular}{|l|l|l|l|l|}
\hline & \multicolumn{2}{|l|}{ LS } & \multicolumn{2}{l|}{ RS } \\
\hline C & $-110.462 * * *$ & $-110.405^{* *}$ & 4.850 & 13.021 \\
& $(-5.523)$ & $(-1.987)$ & $(0.345)$ & $(0.303)$ \\
\hline Log (population) & -1.248 & -2.426 & $-3.259 * * *$ & $-13.529 * * *$ \\
& $(-0.787)$ & $(-0.485)$ & $(-2.951)$ & $(-3.502)$ \\
\hline Log (GDP/per capita) & $18.443^{* * *}$ & $22.037 * * *$ & $7.821^{* * *}$ & $8.804 *$ \\
& $(8.756)$ & $(3.480)$ & $(5.322)$ & $(1.788)$ \\
\hline Banking \& financial services & $3.166 * *$ & & -1.007 & \\
& $(1.987)$ & & $(-0.902)$ & \\
\hline Mobile subscribers & & $-0.590 * *$ & & -.0 .066 \\
& & $(-2.215)$ & & $(-0.323)$ \\
\hline Internet speed & & $0.857 * * *$ & & 0.025 \\
& & $(3.343)$ & & $(0.129)$ \\
\hline
\end{tabular}




\begin{tabular}{|l|l|l|l|l|}
\hline Adj.R2 & 0.087 & 0.171 & & \\
\hline Adj.Rw2 & & & 0.049 & 0.119 \\
\hline F-statistic & 33.488 & 10.681 & & \\
(probability) & $(0.000)$ & $(0.000)$ & & \\
\hline Rn-squared statistic & & & $38.806^{* * *}$ & 17.694 \\
(probability) & & & $(0.000)$ & $(0.001)$ \\
\hline
\end{tabular}

Note: Parentheses are t-value. $* * *, * *, *$ denotes significant at 1,5 , and $10 \%$ respectively.

The results are not so robust, however, there are some important points to be noted. GDP per capita is positively related with international trade significantly. High quality of banking \& financial services and Internet speed also promote exports. The results seem to be as expected. On the other hand, the number of mobile subscribers on exports are not significant in some cases, and they show negative in some cases. It is difficult to determine the reason, however, it is not strongly related to international trade. However, the possibility and usefulness of the mobile internet should not be denied in the field of international trade. Mobile usage in the field of IT will be promoted especially in developing countries.

\section{Conclusion}

This study examined whether or not the IT has increased international trade. In general, IT can play an important role in promoting international trade. Internet usage has impacts not only on our daily lives but also in economic activities by reducing costs and inefficiency.

The results show that GDP per capita is significantly and positively associated with international trade. The improvements of banking \& financial services and Internet speed facilitate exports. However, the number of mobile subscribers is not significant in some cases. The results seem to be strange. On the contrary of the usefulness of the mobile-related technology, its usages have not been related with promoting international trade.

The possibility mobile related IT would be useful and it can be spread at lower costs in some cases, so it would be beneficial especially for developing countries. Mobile has benefits such as no need to carry paper documents, faster information sharing and decision-making, cost-cutting movement, and work balance. If the pros of the spreading use of mobile related IT are large, there is some room for promoting this transition. Security, reliability, and so on are key factors to promote mobile into business, including international trade. In other words, international trade could progress if technology development is made that increases the credibility of mobile. Mobile progress could accelerate international trade. Mobile progress could accelerate international trade.

In large deals, mobile transactions may be shunned. However, in small transactions by individuals and small and medium-sized enterprises, there is also great potential for mobile transactions and settlements. There are many barriers, but the situation could change significantly within a few years. The key to this is the progress of IT.

\section{References}

Abeliansky, A.L., Barbero, J., Rodriguez-Crespo, E., (2021), ICTs quality and quantity and the margins of trade, Telecommunication Policy, 45(1), 102056. https://doi.org/10.1016/j.telpol.2020.102056

Asongu, S.A., (2013), How has mobile phone penetration stimulated financial development in Africa, Journal of African Business, 14(1), 7-18. https://doi.org/10.1080/15228916.2013.765309

Baldwin, R.E., (2006), Multilateralising regionalism: spaghetti bowls as building blocs on the path to global free trade, World Economy, 29(11), 1451-1518.

Billon, M., Rodriguez-Crespo, E., (2020), Impacts on bilateral trade of sub-sahara countries, Estudios de Economia Aplicada, 38(2), 31-43.

Choi, C., Hoon, Y., (2009), The effect of the internet on economic growth: Evidence from cross-country panel data, Economics Letters, 105(1), 39-41. https://doi.org/10.1016/j.econlet.2009.03.028 
Choi, C., (2010), The effect of the Internet on service trade, Economics Letters, 109(2), 102-104. https://doi.org/10.1016/i.econlet.2010.08.005

Clarke, G. R. G., (2008), Has the Internet increased exports for firms from low and middle income countries?. Information Economics and Policy, 20(1), 16-37. https://doi.org/10.1016/j.infoecopol.2007.06.006

Clarke, G.R.G., Wallsten, S.J., (2006), Has the Internet increased trade? Development and developing country evidence, Economic Inquiry, 44(3), 465-484. https://doi.org/10.1093/ei/cbj026

Demir, F., Dahi, O.S., (2011), Asymmetric effects of financial development on South-South and South-North trade: Panel data evidence from emerging markets, Journal of Development Economics, 94(1), 139-149. https://doi.orq/10.1016/j.jdeveco.2009.12.001

Donovan, K., (2012), Mobile money for financial inclusion, Information and Communications foe Development, 61(1), 61-73. https://doi.org/10.1596/9780821389911 ch04

Gnangnon, S.K., (2020), Effect of the Internet on services export diversification, Journal of Economic Integration, 35(3), 519-558. https://doi.org/10.1130/jei.2020.35.519

Gnangnon, S.K., Iyer, H., (2018), Does bridging the internet access divide contribute to enhancing countries' integration into the global trade in services markets?. Telecommunication Policy, 42(1), 61-77. https://doi.org/10.1016/j.telpol.2017.08.004

Hajilee, M., Niroomand, F., (2019), On the link between financial market inclusion and trade openness: An asymmetric analysis, Economic Analysis and Policy, 62, 373-381. https://doi.org/10.1016/j.eap.2018.10.001

Hakanson, L., Dow, D., (2012), Markets and networks in international trade: On the role of distances in globalization, Management International Review, 52(6), 761-789. https://doi.org/10.1007/s11575-012-0142-3

Hjort, J., Poulsen, J., (2019), The arrival of fast Internet and employment in Africa, American Economic review, 109(3), 1032-1079. https://doi.org/10.1257/aer.20161385

Hur, J., Raji, M., Riyanto, Y.E., (2006), Finance and trade: A cross-country empirical analysis on the impact of financial development and asset tangibility on international trade, World Development, 34(10), 1728-1741. https://doi.org/10.1016/j.worlddev.2006.02.003

Kneller, R., Timmis, J., (2016), ICT and exporting: The effects of broad on the extensive margins of business service exports, Review of International Economics, 24(4), 757-796. https://doi.org/10.1111/roie.12237

Krugman, P., (2001), Geography and trade, MIT Press, Cambridge.

Kurihara, Y., Fukushina, A., (2016), Openness of the economy, diversification, specialization, and economic growth, Journal of Economics and Development, 4(1), 31-38

Lin, F., (2015), Estimating the effect of the Internet on international trade, Journal of International Trade and Economic Development, 24(3-4), 409-428. https://doi.org/10.1080/09638199.2014.881906

Meijers, H., (2014), Does the Internet generate economic growth, international trade, or both?. International Economics and Economic Policy, 11(1-2), 137-163. https://doi.org/10.1007/s10368-013-0251-x

Milica, D., (2018), The role of information and communications technology in international trade, Ekonomika, 64(1), 79-94. https://doi.org/10.5937/ekonomika1801079D

Noh, Y. H., Yoo, K., (2008), Internet, inequality and growth, Journal of Policy Modeling, 30(6), 1005-1016. https://doi.org/10.1016/j.jpolmod.2007.06.016

Oliner S. D., Daniel, E. S., (2000), The resurgence of growth in the late 1990s: Is information technology the story?. Journal of Economic Perspectives 14(4), 3-22. https://doi.org/10.1257/jep.14.4.3

Sawadogo, F., Wandaogo, A-A., (2021), Does mobile money services adoption foster intra-African goods trade?. Economics Letters, 199, 109681. https://doi.org/10.1016/j.econlet.2020.109681

Vemuri, V. R., Siddiqi, S., (2009), Impacts of commercialization of the Internet on international trade: A panel study using the extended gravity model, International Trade Journal, 23(4), 456-464. https://doi.org/10.1080/08853900903223792

Visser, R., (2019), The effect of the Internet on the margins of trade, Information Economics and Policy, 46, 41-54. https://doi.org/10.1016/j.infoecopol.2018.12.001

Acknowledgments: I appreciate anonymous referees for their valuable comments and suggestions.

Does this article screened for similarity: YES 
Funding: I was supported by JSPS KAKENHI Grant Number $15 \mathrm{H} 03366$ for this work.

Conflict of Interest: The Author has no conflicts of interest to declare that they are relevant to the content of this article.

\section{About The License}

(C) The author 2021. The text of this article is open access and licensed under a Creative Commons Attribution 4.0 International License

\section{Cite this Article}

Y. Kurihara, Have IT improvements had positive impacts on international trade?, Asian Journal of Interdisciplinary Research, 4(4) (2021) 1-9. https://doi.org/10.34256/ajir2141 